\title{
Intracellular viability in human non-polarized respiratory epithelial 16 HBE 140- cells by group B Streptococcus serotype III clinical isolates presenting $162-\mathrm{kb}$ and $183-\mathrm{kb}$ virulence markers
}

\author{
ADRIANA SÁ DE SãO JOSÉ ${ }^{1,2}$, NEIDE HIROME T. MIYAZAKI ${ }^{3}$, RAPHAEL HIRATA JÚNIOR ${ }^{2}$, \\ ANA LUIZA MATTOS-GUARALDI ${ }^{2}$ and PRESCILLA EMY NAGAO ${ }^{1}$
}

\begin{abstract}
${ }^{1}$ Departamento de Biologia Celular e Genética, Instituto de Biologia Roberto Alcântara Gomes, Universidade do Estado do Rio de Janeiro, R. São Francisco Xavier, 524-PHLC, $2^{\circ}$ andar, 20.550-013 Maracanã; ${ }^{2}$ Disciplina de Microbiologia

e Imunologia, Faculdade de Ciências Médicas, Universidade do Estado do Rio de Janeiro, Av. 28 de Setembro,

87-Fundos, $3^{\circ}$ andar, 20.551-030 Vila Isabel; ${ }^{3}$ Instituto Nacional de Controle de Qualidade em Saúde,

Fundação Oswaldo Cruz, Av. Brasil, 4365-Manguinhos, 21.045-900 Rio de Janeiro, RJ, Brazil
\end{abstract}

Received August 29, 2005; Accepted October 25, 2005

\begin{abstract}
Group B streptococci (GBS), mainly serotype III, are the major cause of neonatal pneumonia, sepsis and meningitis. Virulence potential of GBS strains may determine the outcome of host colonization or infection. Because the lung constitutes a first step in GBS systemic invasion processes, we investigated the adherence and invasion mechanisms of GBS-III clinical isolates to non-polarized human bronchial epithelial $16 \mathrm{HBE} 14 \mathrm{o}-$ cell line. The presence of genotypic $162-\mathrm{kb}$ and $183-\mathrm{kb}$ virulence markers in all strains was also examined by PFGE. The 162-kb fragment was detected in both liquor (GBS-III 90356) and vagina (GBS-III 39A) isolates, while $183-\mathrm{kb}$ fragment was only observed in strains (GBS-III 39A, 89A, and 80340) isolated from vagina of asymptomatic carriers. The actin-dependent ability to internalize within nonpolarized epithelial respiratory cells was demonstrated only by GBS-III clinical isolates presenting the $162-\mathrm{kb}$ virulence marker. GBS-III 39A strain isolated from vagina exhibiting both $183-\mathrm{kb}$ and 162-kb fragments showed a more efficient adherence and invasion properties than GBS-III 90356 isolated from liquor $(\mathrm{P}<0.001)$. Our data suggest the expression of additional bacterial virulence factors that may favor adherence and survival to non-polarized respiratory epithelial cells with
\end{abstract}

Correspondence to: Dr Prescilla E. Nagao, Departamento de Biologia Celular e Genética, Instituto de Biologia Roberto Alcântara Gomes, Universidade do Estado do Rio de Janeiro, R. São Francisco Xavier, 524-PHLC, $2^{\circ}$ andar, 20.550-013 Maracanã, Brazil

E-mail: pnagao@uerj.br

Key words: group B Streptococcus, 16 HBE 140- respiratory epithelial cells, actin polymerization, PFGE virulence marker consequent development of systemic diseases by GBS-III, including some strains isolated from asymptomatic carriers.

\section{Introduction}

Group B streptococci serotype III (GBS-III) is an important cause of infection in neonates and/or infants (30\%), and immunocompromised or pregnant adults $(19 \%)(1,2)$. Maternal colonization and vertical transmission of GBS is found in more than $95 \%$ of neonatal carriers. Prematurity is one of the risk factors for GBS disease, and morbidity and mortality rates are higher among newborns (3). Following infection of the amniotic cavity, GBS infection of the fetus often begins as pneumonia, implicating the lung as the site of initial infection. The infant may directly inhale GBS during birth, which then spreads within respiratory tract and invades the bloodstream and eventually the meninges (4). The serotype-specific capsular polysaccharides are essential for pathogenesis, and serotype III is prevalent among strains isolated from infants with invasive infections (5). Failure of polymorphonuclear leukocytes and pulmonary macrophages to effectively eliminate GBS from the alveolar space and the ability of bacteria to adhere to respiratory epithelial cells are essential for the development of pneumonia (6). The mechanism(s) used by GBS to cause invasive disease are not completely understood, but is clear that GBS are able to invade polarized epithelial cells $(7,8)$. In a number of studies, airway pathogens, such as Haemophilus influenzae, Streptococcus pneumoniae, and Pseudomonas aeruginosa have not adhered well to normal epithelium in vitro, whilst epithelia damage has been noted to increase bacterial adherence (9-11).

Pathogens may manipulate the host cell cytoskeleton to perform specific tasks including uptake of bacteria (invasion) or propelling intracellular bacteria $(8,12)$. Additional studies remain necessary in order to elucidate whether the adhesion process of GBS to respiratory cells is dependent on prior injuries of the respiratory mucosa and recruitment of actin at the site of adherent as previously observed for some airway 
pathogens. The aim of this study was to investigate the adherence and intracellular viability of GBS-III clinical isolates in non-polarized $16 \mathrm{HBE} 14 \mathrm{o}$ - respiratory cells and the involvement of actin filaments of cytoskeleton in these specific tasks.

\section{Materials and methods}

Bacterial strains. GBS-III (80340-vagina, 89A-vagina, 39Avagina and 90356-liquor strains) partially investigated for adhesive properties (13) isolated from patient and asymptomatic carriers were used in the experiments. Microorganisms were identified as group B and serotyped as described previously (14). GBS strains were grown in Brain Heart Infusion broth (BHI; Difco Laboratories, Detroit, MI, USA) at $37^{\circ} \mathrm{C}$, and aliquots were stored at $-70^{\circ} \mathrm{C}$ until used.

Respiratory epithelial cell culture (non-polarized $16 \mathrm{HBE}$ 14o-cell culture). A $16 \mathrm{HBE} 14 \mathrm{o}$ - human bronchial epithelial cell line (15), kindly provided by Dr Maria Cristina Plotkowski (University of California at San Francisco, San Francisco, CA), was grown in 199 culture medium (199 M; Sigma Chemical Co., St. Louis, MO, USA) containing $10 \%$ fetal calf serum, glutamine, and antibiotics (complete culture medium) on film collagen I coated 24-well culture dishes.

Adherence and viable intracellular assays. Aliquots of logphase GBS $\left(10^{7} \mathrm{CFU} / \mathrm{ml}\right)$ were added to each well containing non-polarized $16 \mathrm{HBE} 14 \mathrm{o}$ - cells $\left(10^{5}\right.$ cells $)$ in $0.5 \mathrm{ml} 199 \mathrm{M}$. Infected monolayers were incubated for $0,0.5,1,2,4$ and $6 \mathrm{~h}$, washed three times with phosphate-buffered saline (PBS; $0.14 \mathrm{M} \mathrm{NaCl}, 0.003 \mathrm{M} \mathrm{KCl}, 0.01 \mathrm{M} \mathrm{NaH}_{2} \mathrm{PO}_{4}, 0.0015 \mathrm{M}$ $\mathrm{KH}_{2} \mathrm{PO}_{4}$, $\mathrm{pH}$ 7.3) and, disrupted by $0.5 \mathrm{ml}$ lyses buffer (Tris$\mathrm{HCl}$, pH 7.5 added $250 \mathrm{mM} \mathrm{NaCl}, 5 \mathrm{mM}$ EDTA, $1 \%$ Igepal, $1 \mathrm{mM}$ PMSF and $40 \mu \mathrm{M}$ leupeptin).

Intracellular bacteria were quantified as for the adherence assay added with an antibiotic exposure step. Cells were washed five times with PBS, and then $1 \mathrm{ml} 199 \mathrm{M}$ containing gentamicin $(100 \mu \mathrm{g} / \mathrm{ml})$ and penicillin $\mathrm{G}(5 \mu \mathrm{g} / \mathrm{ml})$ was added to each well. The plates were incubated for $2 \mathrm{~h}$ at $37^{\circ} \mathrm{C}$, washed three times with PBS and the lysate was obtained as described above. The lysate $(50 \mu 1)$ from each well was diluted 1:100 and added to $3.5 \mathrm{ml} \mathrm{BHI-0.7 \%} \mathrm{agar.} \mathrm{Viable} \mathrm{intracellular} \mathrm{bacteria}$ were calculated as $\left[10^{3} \mathrm{x}\right.$ (CFU on plate count/CFU in original inoculums)]. The adherence values were determined by subtracting intracellular bacteria from total cell-associated (intracellular plus surface-adherent) bacteria. All assays were performed in triplicate and repeated three times (16).

Treatment of 16 HBE 14o-cells with cytochalasin E. Nonpolarized $16 \mathrm{HBE} 14 \mathrm{o}$ - cells were pre-treated with $199 \mathrm{M}$ containing $100 \mathrm{nM}$ cytochalasin $\mathrm{E}$ (Sigma) for $20 \mathrm{~min}$ at $37^{\circ} \mathrm{C}$ and then infected with bacterial suspensions $\left(\sim 10^{8} \mathrm{CFU} / \mathrm{ml}\right)$ diluted in 199 medium containing cytochalasin $\mathrm{E}$. The number of viable cell-associated bacteria and intracellular bacteria was determined as described above (17).

Light microscopy (Normaski). 16 HBE 140- monolayers were infected with GBS-III for $1 \mathrm{~h}$ and analyzed by light microscopy using Zeiss-Axioplan microscope equipped with differential interference contrast (DIC) and plan-neofluar objective. A JVC-CCD camera was linked to microscope and the representative images were digitalized using an image processor KS-400 (Zeiss-Vision) (18).

Fluorescent-actin staining (FAS) test. Respiratory epithelial cells 16 HBE 14o- were infected with GBS-III strains. After $120 \mathrm{~min}$, the cells were washed three times with PBS containing $1 \%$ bovine serum albumin (PBS-BSA 1\%) and fixed with $3 \%$ formaldehyde for $1 \mathrm{~h}$. For actin recruitment visualization, $16 \mathrm{HBE} 14 \mathrm{o}$ - cells were permeabilized with PBSBSA $1 \%$ containing $0.1 \%$ Triton for $4 \mathrm{~min}$, washed three times with PBS-BSA $1 \%$ and stained with $5 \mu \mathrm{g} / \mathrm{ml}$ FITC-Phalloidin solution in PBS-BSA $1 \%$ for $30 \mathrm{~min}$. FAS test results were considered positive when foci of intense fluorescence corresponded to areas of bacterial adhesion observed under phase-contrast microscopy (19).

Transmission electron microscopy (TEM). 16 HBE 14omonolayers infected with GBS-III strains were rinsed and fixed with $0.1 \mathrm{M}$ cacodylate buffer $\mathrm{pH} 7.2$ containing $2 \%$ glutaraldehyde, $4 \%$ paraformaldehyde, $5 \mathrm{mM} \mathrm{CaCl}_{2}$ for $1 \mathrm{~h}$ at $4^{\circ} \mathrm{C}$. Monolayers were post-fixed with $1 \% \mathrm{OsO}_{4}, 5 \mathrm{mM} \mathrm{CaCl}_{2}$ and $0.8 \% \mathrm{~K}_{4}\left[\mathrm{Fe}\left(\mathrm{CN}_{6}\right)\right]$ in cacodylate buffer for $1 \mathrm{~h}$ at $22^{\circ} \mathrm{C}$, and dehydrated through a series of graded ethanol solutions and embedded in Epon. Ultra-thin sections were examined under Zeiss EM 906 transmission electron microscope (Zeiss, Oberkochen, Germany) (20).

Chromosome analysis by pulsed-field gel electrophoresis $(P F G E)$. For PFGE analysis, two or three colonies were picked from a fresh plate of overnight growth and incubated in $5.0 \mathrm{ml}$ of Todd-Hewitt broth for $5 \mathrm{~h}$ at $35^{\circ} \mathrm{C} ; 1.5 \mathrm{ml}$ of this suspension was centrifuged at $2000 \times \mathrm{g}$ for $10 \mathrm{~min}$, and the pellet was resuspended in $0.6 \mathrm{ml}$ of Tris- $\mathrm{NaCl}$ buffer $(1.0 \mathrm{M} \mathrm{NaCl}$ in $10 \mathrm{mM}$ Tris- $\mathrm{HCl}, \mathrm{pH} 7.6)$. Then, $0.6 \mathrm{ml}$ of $2 \%$ low-meltingtemperature agarose (Bio-Rad Laboratories, Richmond, CA) in Tris- $\mathrm{NaCl}$ buffer was added. The agarose-bacterium mixtures were poured into plug molds (Bio-Rad). Solidified plugs were lysed overnight at $37^{\circ} \mathrm{C}$ with $1.0 \mathrm{ml}$ of lyses solution $(6 \mathrm{mM}$ Tris- $\mathrm{HCl} \mathrm{pH} 8.0,1.0 \mathrm{M} \mathrm{NaCl}, 0.2 \%$ sodium deoxycolate, $0.5 \%$ sodium lauroyl sarcosine, $1 \mathrm{mg} / \mathrm{ml}$ of lysozyme, $50 \mathrm{U} / \mathrm{ml}$ of mutanolysin, $\mathrm{pH}$ 7.6). This was followed by incubation for $24 \mathrm{~h}$ in a $50^{\circ} \mathrm{C}$ shaking water bath in EDTA-sarcosineproteinase solution ( $0.5 \mathrm{M}$ EDTA, $1 \%$ sodium lauroyl sarcosine, $0.1 \mathrm{mg} / \mathrm{ml}$ proteinase $\mathrm{K}, \mathrm{pH} 9.0$ ). The plugs were washed six times, for $2 \mathrm{~h}$ each time, in Tris-EDTA buffer (10 mM Tris-HCl, $0.1 \mathrm{mM}$ EDTA, $\mathrm{pH}$ 7.6) and stored in the same buffer at $4^{\circ} \mathrm{C}$. The plugs were incubated with $8 \mathrm{U}$ of SmaI (Boehringer-Mannheim Biochemicals, Indianapolis, IN) $24-48 \mathrm{~h}$ at $25^{\circ} \mathrm{C}$, heated for a few minutes at $72^{\circ} \mathrm{C}$ to melt the plugs, and dispensed into wells of a $1 \%$ pulsed-field grade agarose gel (Bio-Rad). The chromosomal digests were separated by PFGE with a switch time of $1-50 \mathrm{sec}$ for $25 \mathrm{~h}$ at a $120^{\circ}$ angle with a voltage gradient of $6 \mathrm{~V} / \mathrm{cm}$ at $10^{\circ} \mathrm{C}$. The DNA size standard used was a lambda DNA ladder (BioRad). Gels Ewer stained with ethidium bromide and the patterns were digitized and analyzed by using the software BioNumeric version 2.0, Applied Maths BVBA, Kortrijk, Belgium (16). 

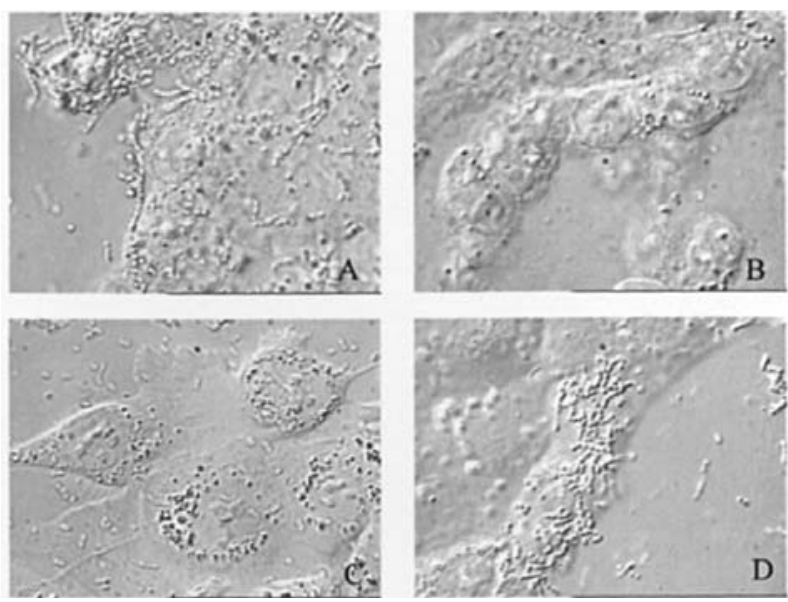

Figure 1. Light Normaski microscopy of $16 \mathrm{HBE} 14 \mathrm{o}-$ cells (A) infected with GBS-III 80340-vagina, (B) 89A-vagina, (C) 39A-vagina, and (D) 90356-liquor strains. Magnification x40.

Table I. Adherence and intracellular viability $(\mathrm{CFU} / \mathrm{ml})$ of GBS-III strains to non-polarized $16 \mathrm{HBE} 14 \mathrm{o}-$ cells.

\begin{tabular}{|c|c|c|c|}
\hline $\begin{array}{l}\text { GBS-III } \\
\text { strains }\end{array}$ & $\begin{array}{l}\text { Incubation } \\
\text { time (h) }\end{array}$ & Adherence & $\begin{array}{c}\text { Intracellular } \\
\text { viability }\end{array}$ \\
\hline \multirow[t]{6}{*}{ 80340-vagina } & 0 & $3.13 \times 10^{4}$ & 0 \\
\hline & 0.5 & $1.43 \times 10^{5}$ & 0 \\
\hline & 1 & $3.38 \times 10^{5 a}$ & 0 \\
\hline & 2 & $1.50 \times 10^{5}$ & 0 \\
\hline & 4 & $1.00 \times 10^{4}$ & 0 \\
\hline & 6 & 0 & 0 \\
\hline \multirow[t]{6}{*}{ 89A-vagina } & 0 & $1.88 \times 10^{2}$ & 0 \\
\hline & 0.5 & $4.81 \times 10^{4}$ & 0 \\
\hline & 1 & $2.37 \times 10^{4}$ & 0 \\
\hline & 2 & $1.76 \times 10^{5 \mathrm{a}}$ & 0 \\
\hline & 4 & 0 & 0 \\
\hline & 6 & 0 & 0 \\
\hline \multirow[t]{6}{*}{ 39A-vagina } & 0 & $2.75 \times 10^{4}$ & $5.83 \times 10^{2}$ \\
\hline & 0.5 & $1.88 \times 10^{6}$ & $1.50 \times 10^{3}$ \\
\hline & 1 & $2.80 \times 10^{5}$ & $4.17 \times 10^{3}$ \\
\hline & 2 & $9.72 \times 10^{5}$ & $3.00 \times 10^{3}$ \\
\hline & 4 & $4.40 \times 10^{6}$ & $2.95 \times 10^{4}$ \\
\hline & 6 & $4.21 \times 10^{7 \mathrm{a}}$ & $1.42 \times 10^{7 \mathrm{a}}$ \\
\hline \multirow[t]{6}{*}{ 90356-liquor } & 0 & 0 & 0 \\
\hline & 0.5 & $6.50 \times 10^{3}$ & $1.00 \times 10$ \\
\hline & 1 & $5.00 \times 10^{3}$ & $6.67 \times 10^{2}$ \\
\hline & 2 & $4.21 \times 10^{4}$ & $7.50 \times 10^{3}$ \\
\hline & 4 & $4.18 \times 10^{5 \mathrm{a}}$ & $1.53 \times 10^{4 a}$ \\
\hline & 6 & $1.08 \times 10^{4}$ & $1.00 \times 10^{3}$ \\
\hline
\end{tabular}

${ }^{\mathrm{a}} \mathrm{P} \leq 0.05$.

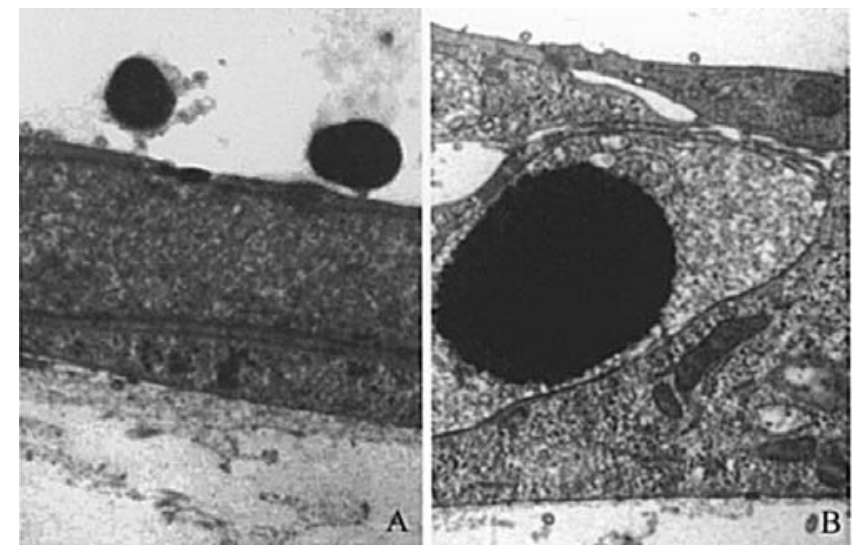

Figure 2. TEM micrographs of $16 \mathrm{HBE} 140-$ cells infected with GBS-III 39A-vagina strain. GBS-III 39A attached to the respiratory epithelial cell surface (A, magnification x7750) and inside $16 \mathrm{HBE} 140-$ compartment (B, magnification $\mathrm{x} 16000)$.

Statistical analysis. Each experiment was carried out in quadruplicate. Student's t-test was used to compare means of experiments.

\section{Results}

Bacterial adherence and intracellular viability. All GBS strains adhered to non-polarized $16 \mathrm{HBE} 140$ - respiratory cells as illustrated by the Normaski differential microscopy (Fig. 1). Results of adherence and intracellular viability at different levels of GBS-III clinical isolates to non-polarized cells are presented in Table I. Adherence of GBS 90356-liquor isolate was detected 30 min to $6 \mathrm{~h}$ after infection of monolayers, with maximum adherence level after 4-h incubation $\left(4.18 \times 10^{5} \mathrm{CFU} /\right.$ $\mathrm{ml} ; \mathrm{P} \leq 0.03)$. Adherence of all GBS vagina isolates was observed immediately after infection (T0 h). Similar to GBS 90356-liquor isolate, the GBS 39A strain was the only vagina isolate that showed adherence after 6-h incubation. Although the maximum adherence level of GBS 39A-vagina strain occurred $2 \mathrm{~h}$ later than GBS 90356-liquor strain, the GBS 39Avagina strain showed higher adherence index $\left(4.21 \times 10^{7} \mathrm{CFU} /\right.$ $\mathrm{ml}$ and $4.18 \times 10^{5} \mathrm{CFU} / \mathrm{ml}$, respectively). The GBS 39A-vagina isolates also exhibited a higher intracellular survival ability

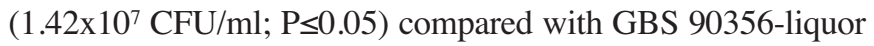
isolate. Transmission electron micrographs (TEM; Fig. 2) revealed GBS-III vagina isolate attached to and inside nonpolarized respiratory epithelial $16 \mathrm{HBE} 14 \mathrm{o}$ - cells.

Pulsed-field gel electrophoresis. The PFGE virulence marker of 162-kb was detected in GBS-III 90356-liquor and 39Avagina strains and the $183-\mathrm{kb}$ virulence marker in the GBS-III 39A, 89A, and 80340 isolated from vagina (Fig. 3).

Fluorescent-actin staining (FAS) - test and cytochalasin E inhibition assay. Binding of GBS-III clinical isolates to the respiratory epithelial cell surface led to accumulation of polymerized actin beneath adherent bacteria, as demonstrated by the positive results of FAS test as shown by GBS-III 39Avagina (Fig. 4A and B) and 90356-liquor (Fig. 4C and D) strains. 


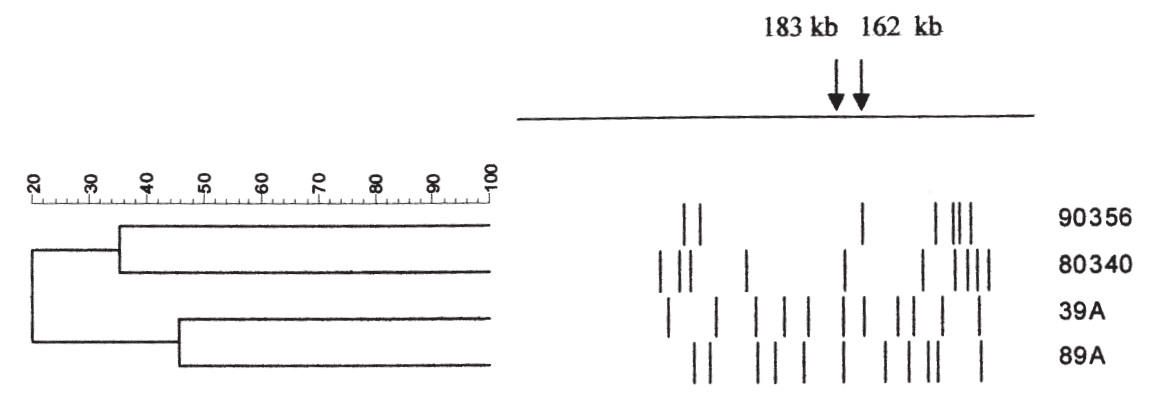

Figure 3. Schematic representation of PFGE patterns obtained after restriction with SmaI. 162-kb and 183-kb fragments identified as a marker of virulence factors of GBS-III strains are also noted.

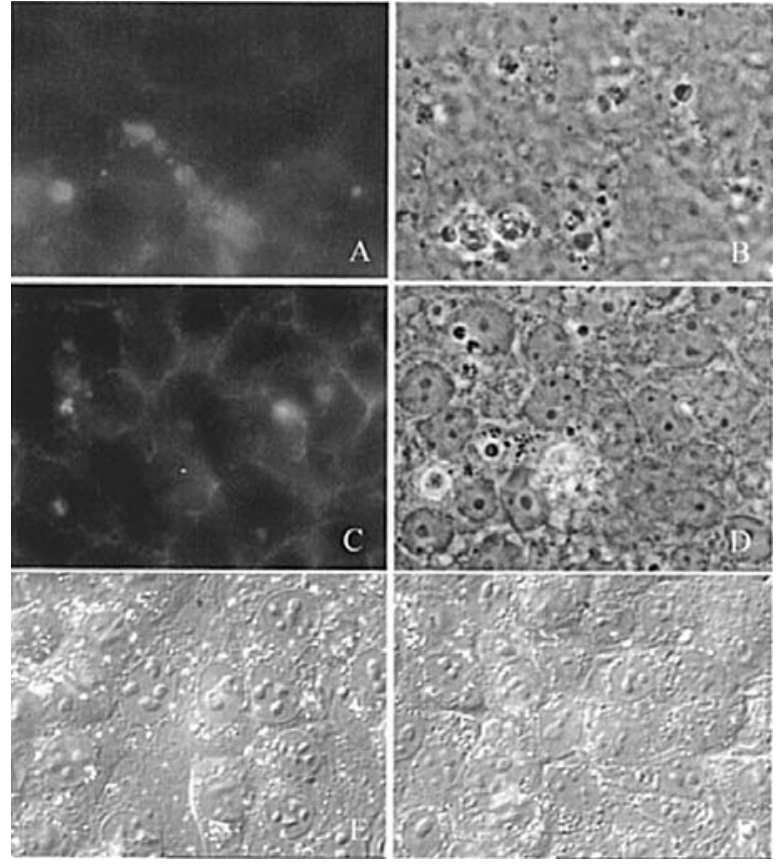

Figure 4. 16 HBE 14o- cell actin recruitment to the site of GBS strains binding observed in ultraviolet rays epi-illumination optical microscopy (A and C) and in trans-illumination optical microscopy by phase contrast microscopy (B and D). 16 HBE 140- cells untreated-(E) and treated-cytochalasin (F). 16 HBE 14o- cells infected with GBS-III 39A-vagina (A and B) and GBS-III 90356-liquor (C and D).

Table II. Adherence and intracellular viability (CFU/ml) of GBS-III clinical isolates after treatment of non-polarized 16 HBE 14o-cells with cytochalasin E.

\begin{tabular}{|c|c|c|c|}
\hline $\begin{array}{l}\text { GBS-III } \\
\text { strains }\end{array}$ & $\begin{array}{l}\text { Incubation } \\
\text { time (h) }\end{array}$ & $\begin{array}{l}\text { Adherence } \\
\text { (\% decrease) }\end{array}$ & $\begin{array}{l}\text { Intracellular } \\
\text { viability } \\
\text { (\% decrease) }\end{array}$ \\
\hline 80340 -vagina & 1 & $4.93 \times 10^{4}(85)$ & $2.10 \times 10^{4}(100)^{\mathrm{a}}$ \\
\hline 89A-vagina & 2 & $1.60 \times 10^{5}(91)$ & $5.33 \times 10^{5}(100)^{\mathrm{a}}$ \\
\hline 39A-vagina & 6 & $1.35 \times 10^{7}(68)$ & $3.70 \times 10^{4} \quad(98)$ \\
\hline 90356-liquor & 4 & (100) & (100) \\
\hline
\end{tabular}

Increase; $\mathrm{P}<0.05$.
Results of interaction of GBS-III clinical isolates with cytochalasin E-treated monolayers are presented in Table II. Peaks of GBS adherence were reduced at different levels after treatment of host cells with cytochalasin E. Inhibition of cytoskeleton led to a maximum decrease of adherence of GBS 90356-liquor strain. Data suggest differences in actin filaments recruitment during interaction of GBS-III with non-polarized respiratory epithelial cells. Cytochalasin E treatment also influenced the intracellular viability of GBS-III strains to non-polarized $16 \mathrm{HBE}$ 140- cells in different manner. In contrast to observations with untreated monolayers, both 80340- and 89A-vagina isolates exhibited intracellular viability within cytochalasin E-treated-16 HBE 14o- cells. Interestingly, both 39A-vagina and 90356-liquor strains showed a strong decrease (98\% and $100 \%$, respectively) in the survival ability within cytochalasin E-treated-16 HBE 14o- cells. Cytochalasin treatment did not influence morphologic characteristics of 16 HBE $140-$ cells as demonstrated by Normasky microscopy (Fig. 4E and F).

\section{Discussion}

GBS are important human pathogens especially in neonatal sepsis and pneumonia (21). Bacterial colonization of the airways usually results from previous damage to host defense mechanisms and bacterial virulence. In order to persist successfully as a respiratory pathogen, bacteria have to be well equipped to rapidly penetrate the mucus layer, to find the host cell surface receptors and to attach to them (22). Clinical observations may not only be related to specific serotypes of GBS, but may also be related to route of invasion and involve consideration of the immune capabilities of the host. It is necessary to evaluate the virulence of isolates recovered from vaginal cultures taken from asymptomatically infected women to determine whether the host will exhibit selective susceptibility to the virulence of the strain.

Microorganisms that cause invasive disease in previously healthy individuals are usually more virulent than those causing bronchial infections (23). Some bacterial pathogens can induce their own uptake into host cells (invasion), allowing it to enter a protected niche and, in some cases, enabling to pass through cellular barriers including the respiratory epithelium and/or the blood-brain barrier. Similarly to most human respiratory pathogens, GBS may cause damage to the lungs due to induction of inflammatory cytokines and free oxygen radicals by activated alveolar macrophages (21). During previous 
investigations the meningitis (GBS-III 90356) isolate showed a stronger ability to survive within human peripheral blood monocytes and macrophages than the vagina GBS-III 80340 isolate (13). Herein, the vagina isolate (GBS-III 80340) was unable to survive within respiratory epithelial cells. In addition to GBS-III strain isolated from liquor from a fatal case of meningitis, all vagina isolates of asymptomatic carriers were capable of adherence to non-polarized respiratory epithelial cells. One of the strains (GBS-III 39A) isolated from vagina showed a higher ability to adhere and survive within $16 \mathrm{HBE}$ 14o- cells when compared to the liquor isolate (GBS-III 90356). Thus, specific GBS-III vagina isolates of asymptomatically infected women seems to exhibit selective ability to injure the lower respiratory tract surfaces. The data suggest that GBS-III strains exhibit differences in their virulence properties. Some, but not all, GBS-III strains seem capable of causing invasive systemic infections.

Bacterial invasion may be initiated by ligand-receptor interactions that activate host signaling, with the actin cytoskeleton providing the necessary force to bacterial internalization (24). Similar to that observed for other invasive bacteria, internalization of GBS-III 39A-vagina and 90356-liquor strains into non-polarized $16 \mathrm{HBE} 14 \mathrm{o}-$ cells was highly inhibited $(98 \%-100 \%)$ by cytochalasin E. Reorganisation of the host cell actin cytoskeleton is associated with invasion by several other bacterial pathogens and is believed to play a role in facilitating bacterial uptake (17). Unexpectedly, both GBS-III 80340- and 89A-vagina isolates became viable within the intracellular environment of respiratory epithelial cells after inhibition of actin polymerization by cytochalasin. The possibility of expression of cytolysin/invasin molecules induced by cytochalasin in some GBS-III, remain under investigation.

Epidemiological investigation has determined that genomovar III strains can be highly transmissible, and there is a clear association between interpatient spread and the presence of a genetic marker [B. cepacia epidemic strain marker (BCESM)] that may play a role in transcriptional regulation (25). Both of these markers may be associated with cystic fibrose lung infections, but a link between these markers and pathogenesis has yet to be established.

For GBS-III, potential PFGE markers of 162-kb and $183-\mathrm{kb}$ seemed to contain genes encoding virulence factors (26). Only the 162-kb fragment has been associated with the source of the GBS-III, being mostly present among isolates from the central nervous system of neonates. The $162-\mathrm{kb}$ virulence marker has been also detected among GBS-III strains isolated from asymptomatic adults $(16,26)$. At present, 162-kb fragment was detected in both liquor (GBS-III 90356) and vagina (GBS-III 39A) isolates presenting the ability to invade epithelial respiratory cells. The $183-\mathrm{kb}$ fragment was only observed in strains (GBS-III 39A, 89A, and 80340) isolated from vagina of asymptomatic carriers.

Presently, the 162-kb fragment was also identified as a virulence marker of invasiveness to human respiratory cells by some GBS-III strains. GBS-III 39A strain isolated from vagina exhibiting both $183-\mathrm{kb}$ and $162-\mathrm{kb}$ fragments showed a more efficient adherence and invasion properties than GBS-III 90356 isolated from liquor. This finding may favor a preliminary correlation of specific sub-group of GBS-III isolates from asymptomatic women with the possibility of invasiveness to cellular barriers during pregnancy and development of neonatal disease.

\section{Acknowledgements}

This work was supported by grants from CNPq, CAPES, FAPERJ, SR-2/UERJ and Programa de Núcleo de Excelência (PRONEX) of the Brazilian Ministry of Science and Technology.

\section{References}

1. Hill HR: Group B streptococcal infections. In: Sexually transmitted diseases. Holmes KK, Mardh PA, Sparling PF, Wiesner PJ, Cates W, Lemon SM and Stamm WE (eds). McGraw Hill Press, New York, NY, pp851-861, 1990.

2. Farley MM: Group B streptococcal disease in nonpregnant adults. Clin Infect Dis 33: 556-561, 2001.

3. Gibbs RS, Schrang S and Schuchat A: Perinatal infections due to group B streptococci. Obstet Gynecol 104: 1062-1076, 2004.

4. Schuchat A: Group B streptococcus. Lancet 353: 51-56, 1999.

5. Tamura GS, Kuypers JM, Smith S, Raff H and Rubens CE: Adherence of group B streptococci to cultured epithelial cells: roles of environmental factors and bacterial surface components. Infect Immun 62: 2450-2458, 1994.

6. Goodrum KJ and Poulson-Dunlap J: Cytokine responses to group B streptococci induces nitric oxide production in respiratory epithelial cells. Infect Immun 70: 49-54, 2002.

7. Rubens CE, Smith S, Hulse M, Chi EY and van Belle G: Respiratory epithelial cell invasion by group B streptococci. Infect Immun 60: 5157-5163, 1992.

8. Tyrrell GJ, Kennedy A, Shokoples SE and Sherburne RK: Binding and invasion of HeLa and MRC-5 cells by Streptococcus agalactiae. Microbiology 148: 3921-3931, 2002.

9. Read RC, Wilson R, Rutman A, Lund V, Todd HC, Brain AP, Jeffery PK and Cole PJ: Interaction of nontypable Haemophilus influenzae with human respiratory mucosa in vitro. J Infect Dis 163: 549-558, 1991 .

10. Feldman C, Read R, Rutman A, Jeffery PK, Brain AP, Lund V, Mitchell TJ, Andrew PW, Boulnois GJ and Todd HC: The interaction of Streptococcus pneumoniae with intact human respiratory mucosa in vitro. Eur Respir J 5: 576-585, 1992.

11. Tsang KW, Rutman A, Tanaka E, Lund V, Dewar A, Cole PJ and Wilson R: Interaction of Pseudomonas aeruginosa with human respiratory mucosa in vitro. Eur Respir J 7: 1746-1753, 1994.

12. Rosenshine I: Cytoskeleton rearrangements induced by bacterial pathogens. In: Bacterial Pathogeneses. Peter W, Julian K and George S (eds). Methods Microbiol Press, New York, NY, pp499-507, 1998.

13. Peotta VA, Ribeiro FL, Arnholdt ACV and Nagao PE: Human monocytes and monocyte-derived macrophages phagocytosis of serotype III group B streptococci strains. Curr Microbiol 43: 64-68, 2001.

14. Lancefield RC: A serological differentiation of specific types of bovine hemolytic streptococci (group B). J Exp Med 59: 441-458, 1934.

15. Plotkowski MC, Bentzmann S, Pereira SH, Zahm JM, BajoletLaudinat O, Roger P and Puchelle E: Pseudomonas aeruginosa internalization by human epithelial respiratory cells depends on cell differentiation, polarity, and junctional complex integrity. Am J Respir Cell Mol Biol 20: 880-890, 1999.

16. Santos GS, Miyazaki NH, Mattos-Guaraldi AL and Nagao PE: The effects of interferon-gamma and transforming growth factorbeta on adherence and survival of group B streptococcus type III strains in ECV304 cells. Int J Mol Med 11: 401-406, 2003.

17. Wells CL, van de Westerlo EM, Jechorek RP, Haines HM and Erlandsen SL: Cytochalasin-induced actin disruption of polarized enterocytes can augment internalization of bacteria. Infect Immun 66: 2410-2419, 1998.

18. Campanati L and Monteiro-Leal LH: The effects of the antiprotozoal drugs metronidazole and furazolidone on trophozoites of Giardia lamblia (P1 strain). Parasitol Res 88: 80-85, 2002.

19. Hirata R Jr, Napoleão F, Monteiro-Leal LH, Andrade AF, Nagao PE, Formiga LC, Fonseca LS and Mattos-Guaraldi AL: Intracellular viability of toxigenic Corynebacterium diphtheriae strains in HEp-2 cells. FEMS Microbiol Lett 215: 115-119, 2002. 
20. Teixeira CF, Azevedo NL, Carvalho TMU, Fuentes J and Nagao PE: Cytochemical study of Streptococcus agalactiae and macrophage interaction. Microsc Res Tech 54: 254-259, 2001.

21. Talati AJ, Crouse DT, English BK, Newman C, Harrison L and Meals EV: Immunomodulation by exogenous surfactant: effect on TNF-alpha secretion and luminol-enhanced chemiluminescence activity by murine macrophages stimulated with group $B$ streptococci. Microbes Infect 3: 267-273, 2001.

22. Plotkowski MC, Bajolet-Laudinat O and Puchelle E: Cellular and molecular mechanisms of bacterial adhesion to respiratory mucosa. Eur Respir J 6: 903-916, 1993.

23. Wilson R, Dowling RB and Jackson AD: The biology of bacterial colonization and invasion of the respiratory mucosa. Eur Respir J 9: 1523-1530, 1996.
24. Finlay BB and Cossart P: Exploitation of mammalian host cell functions by bacterial pathogens. Science 276: 718-725, 1997.

25. Melnikov A, Zaborina O, Dhiman N, Pranhakar BS, Chakrabarty AM and Hendrickson W: Clinical and environmental isolates of Burkholderia cepacia exhibit differential cytotoxicity towards macrophages and mast cells. Mol Microbiol 36: 1481-1493, 2000.

26. Rolland K, Marois C, Siquier V, Carttier B and Quentin R: Genetic features of Streptococcus agalactiae strains causing severe neonatal infections, as revealed by pulsed-field gel electrophoresis and $h y l B$ gene analysis. J Clin Microbiol 37: 1892-1898, 1999. 